\title{
Biodiversity conservation in the Gulf of Guinea islands: taking stock and preparing action
}

\author{
JAVIER JUSTE B \\ Estación Biológica de Doñana (CSIC), Sevilla 41013, Spain
}

JOHN E. FA

Jersey Wildlife Preservation Trust, Les Augrès Manor, Trinity, Jersey JE3 5BF, Channel Islands, UK

Received 5 August 1994; accepted 6 August 1994

This paper introduces an Action Statement on biodiversity conservation in the four Gulf of Guinea islands arising from a workshop held in Jersey in 1993. The current state of the main habitats on all the islands, pressures acting upon them, existing institutions and actions taken so far are reviewed. The 24-point Action Statement was produced as a framework for future international initiatives in biodiversity research and conservation in this part of Africa. Attention is drawn to the progress made by the governments of the region in legislation and institutional support. The workshop recommended the establishment of a regional programme of research and conservation in conjunction with the Governments of Equatorial Guinea and of São Tomé and Principe.

Keywords: biodiversity, protection, conservation, Gulf of Guinea, São Tomé, Principe, Bioko, Annobón

\section{Introduction}

The Gulf of Guinea islands include Bioko, the largest, São Tomé, Príncipe and Annobón, the smallest. Bioko and Annobón are part of the Republic of Equatorial Guinea (formerly a Spanish colony) and São Tomé and Principe (once Portuguese enclaves) form a separate country (the Democratic Republic of São Tomé and Príncipe) and one of the smallest in the world.

During the early 1800 s and the start of this century all four Guinea islands were studied by naturalists who unquestionably recognized their biological wealth. Despite this, the islands still remain relatively unknown as a result of disruptions in both countries caused by the rise of dictatorships after independence. It was not until political normality was restored as late as 1979 that studies could start again. However, these did not resume until 1984 on Bioko and later for São Tomé and Príncipe, mostly by European and North American organizations. First results were most encouraging in terms of new species found and the discovery that habitats were in general little modified. This has encouraged the World Conservation Union (IUCN) and BirdLife International, among others, to recognize these islands as being critical areas for African biodiversity conservation (Fa, 1991; Jones et al., 1991; Bibby et al., 1992; Juste, 1992).

Although there is still the need for increased knowledge of the islands' biodiversity, there is, more importantly, the real urgency for direct conservation action to be taken. 
Immediately after political normality, the islands have suffered from increasing economic pressures and have turned to natural resource exploitation as their panacea. Use of the environment is uncontrolled and if it continues at current levels, it will, without any doubt lead to an even more dramatic socioeconomic situation. Because these islands make up a unique biogeographic unit there is a clear place for a regional approach to biodiversity conservation.

A first step forward is to perform stock-taking and action planning by assembling existing data and expertise. This was the main aim of a workshop organized at the Jersey Wildlife Preservation Trust in Jersey on 4-6 June 1993, which gathered most scientists working on biodiversity in the Gulf of Guinea islands. The body of knowledge and experience assembled at the meeting was unparalleled given that the majority of researchers who have worked on the islands since independence attended. This paper provides an overview of the physical and biological setting of each island, detailed aspects of current conservation action, and presents an action statement for further research and conservation which was agreed at the workshop.

\section{The Gulf of Guinea islands}

Bioko $\left(3^{\circ} 48^{\prime}-3^{\circ} 12^{\prime} N\right.$; $\left.8^{\circ} 25^{\prime}-8^{\circ} 57^{\prime} E\right)$

This island (formerly Fernando Poo) is rectangular in shape $(69 \times 32 \mathrm{~km})$ and has an area of $2017 \mathrm{~km}^{2}$ (Fig. 1). It is situated on the continental platform, separated from the Cameroon coast by no more than $32 \mathrm{~km}$. Administratively, Bioko forms part of the insular sector of the Republic of Equatorial Guinea and is the location of the country's capital, Malabo (formerly Santa Isabel).

Principe $\left(1^{\circ} 32^{\prime}-1^{\circ} 43^{\prime} N ; 7^{\circ} 20^{\prime}-7^{\circ} 28^{\prime} E\right)$

Principe is located $210 \mathrm{~km} \mathrm{S-SW}$ of Bioko and $220 \mathrm{~km} \mathrm{~W}$ off the African continent (Fig. 1). Like Bioko, it is rectangular in shape $(17 \times 8 \mathrm{~km})$ and has an area of $128 \mathrm{~km}^{2}$. Príncipe is a province of the Democratic Republic of São Tomé and Príncipe.

São Tomé $\left(0^{\circ} 25^{\prime}-0^{\circ} 01^{\prime} N ; 6^{\circ} 28^{\prime}-6^{\circ} 45^{\prime} E\right)$

São Tomé is situated $150 \mathrm{~km} \mathrm{S-SW}$ of Príncipe and $225 \mathrm{~km}$ from Gabon (Fig. 1). Its shape is essentially elliptical $(47 \times 27 \mathrm{~km})$ and covers $836 \mathrm{~km}^{2}$. This island is also a separate province within the Republic of São Tomé and Príncipe.

Annobón $\left(1^{\circ} 24^{\prime}-1^{\circ} 28^{\prime} S ; 5^{\circ} 36^{\prime}-5^{\circ} 38^{\prime} E\right)$

This is the smallest and most distant island of the group, lying about $180 \mathrm{~km}$ south of São Tomé and $340 \mathrm{~km}$ west of Port Gentil (Gabon) (Fig. 1). It is elongated $(7 \times 2.5$ $\mathrm{km}$ ) and covers only $17 \mathrm{~km}^{2}$. The island is a province within the Republic of Equatorial Guinea.

\section{The physical setting}

The four Guinea islands are the result of volcanic eruptions along a fracture stretching NE-SW from Mounts Kupe and Manenguba on the continent (Eisentraut, 1963) to St Helena in the South Atlantic (Teran, 1962). The subsequent sinking of the platform has 
(a)

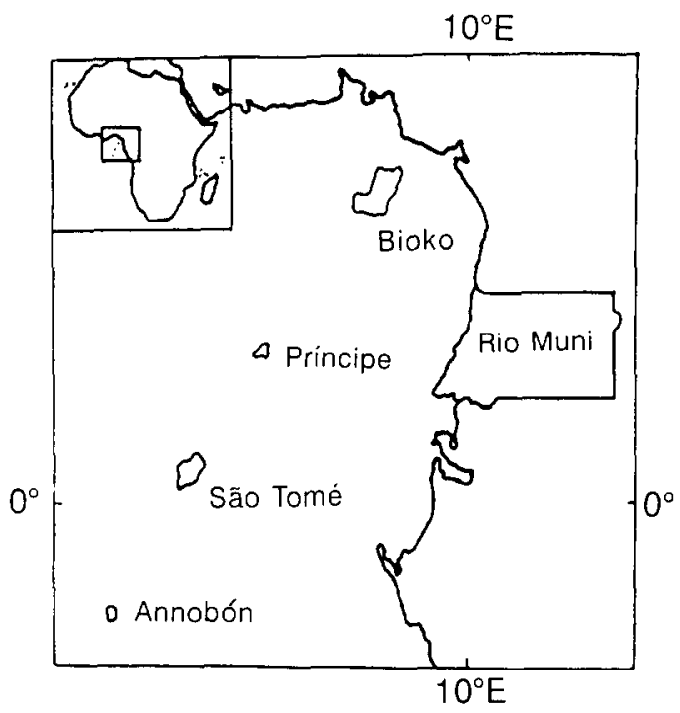

(b)

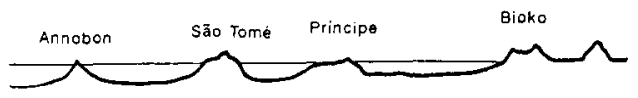

Figure 1. (a) Gulf of Guinea islands in relation to West Africa. (b) Elevation of the mountain chain (adapted from Hodges and Newitt, 1988).

tilted the islands towards the southwest; this tilt is a marked feature of their modern geography.

Geological evidence suggests that the islands were formed around the same time during the Lower Tertiary and early Quaternary (Dos Santos, 1943; Fuster, 1950; Teran, 1962) but were shaped by activity during the Pleistocene (Eisentraut, 1963). The result has been the deposition of younger rocks on the predominant older and denser basalts (Fuster, 1954).

The recent origin of the four islands is reflected in their very abrupt and dramatic landscapes made up by deep valleys, crests, peaks and volcanic calderas. Bioko is dominated by two main volcanic massifs connected by a central depression; maximum elevation being $3011 \mathrm{~m}$ at Pico Basilé. São Tomé and Príncipe have steeper terrain carved by numerous rivers and waterfalls. This is typical of the central and southern parts of the islands (which are composed of younger phonolite rocks) and contrast with the older basalts that make up the gentler slopes $(<10 \%)$ in the north. In Principe, there are two mountain chains which run approximately from east to west, but the two São Tomé chains are found one from north to south and the other running northwest to southeast. Highest peaks reach $2024 \mathrm{~m}$ in São Tomé but only $948 \mathrm{~m}$ in Príncipe; these peaks are found in the centre of both islands. Annobón, despite its small size, is also relatively abrupt with elevations at Quiveo and Santa Mina well above $600 \mathrm{~m}$. 
The rivers on the islands drain radially from the main volcanic massifs. These are mostly fast-flowing, perennial streams (with important seasonal fluctuations), often with relatively short water courses and interrupted by waterfalls. On Bioko, the major rivers are the Tiburones on the west and the Musola on the east. However, the entire island is heavily dissected by numerous streams descending from their source in Pico Basile and the Southern Highlands (Castelo, 1994). On São Tomé, the western part of the island is drained by the Io Grande, the largest river of the islands. Other important rivers on this island, of almost equal size, are the Abade and Manuel Jorge. The longest river on Principe is the Papagaio, which flows through the town of Santo Antonio.

Seasons are determined on the islands by the movement of the inter-tropical front, the meeting of the hot dry air of the Sahara with the moist air of the Atlantic. The islands' climate is affected by the dominance of the southerly winds and the Atlantic calms, or doldrums, interacting with the warm Guinea current and modified even further by relief (Wauthy, 1983; Louzoun, 1985). Thus the Guinea islands have a typically oceanic equatorial climate with temperatures above $25^{\circ} \mathrm{C}$ at sea level but lower at higher altitudes; $5^{\circ} \mathrm{C}$ at the summit of Pico Basilé (Capuz, 1961). Rainfall decreases in a SW-NE direction in all the islands but there are significant rain shadows especially on the north-facing slopes. Precipitation of over $11000 \mathrm{~mm}$ is typical along the south of Bioko (Teran, 1962). Maximum precipitation on São Tomé is $7000 \mathrm{~mm}, 5000 \mathrm{~mm}$ on Príncipe (Louzan, 1985) and up to $3000 \mathrm{~mm}$ on Annobón.

In Bioko, the movement of the inter-tropical front northwards and southwards causes the two main precipitation maxima to coincide on the south of the island (Teran, 1962). Elsewhere on Bioko where the front moves northwards this causes a main dry season (seca) between December and February (average monthly rain $<100 \mathrm{~mm}$ ) and a shorter one (sequilla) (average monthly rain $<500 \mathrm{~mm}$ ) from July to August. In São Tomé and Príncipe there is a main dry period (gravana) from June to September and a less severe one (gravanito) between December and February. These periods are slightly out of phase between Príncipe and São Tomé due to latitude differences. In contrast to the other islands, Annobón, is affected primarily by the oceanic winds which cause a very pronounced dry season (May-October) and a wet one between November and April.

\section{The biological setting of the Gulf of Guinea islands}

Comparisons of the fauna and flora of the Guinea islands can be found in Jones (1994) and in Figueiredo (1994) respectively. In the context of this paper, it suffices to allude to the fact that the complex biogeography of the islands' biota is reflected by their different geological history. Because Bioko was connected to the mainland during the Pleistocene, species richness in plants (Exell, 1973; Figueiredo, 1994), birds (Amadon, 1953; Peet and Atkinson, 1994), butterflies (Viejo, 1990), bats (Juste and Ibañez, 1994) and terrestrial molluscs (Gascoigne, 1994) illustrate how the fauna and flora in São Tomé, Príncipe and Annobón have originated by drift colonization from the continent. Of biogeographical interest is the unexplained presence of shrews (Heim de Balsac and Hutterer, 1982), caecilians and amphibians on São Tomé and Príncipe (Fahr, 1993).

The habitats found in all the islands have been conditioned by the rugged terrain and wide altitudinal ranges (from almost sea level to over $3000 \mathrm{~m}$ ). Extreme variation in precipitation also play a significant role in determining the range of vegetation types. The predominant type on all the islands, at least until the advent of man, is tropical 
rainforest. Forest cover is still high but composition has changed as a result of human activity (see below).

The islands' vegetation is characterized by altitudinal belts related to differences in precipitation and temperatures. Generally, lowland rain forest is succeeded by montane forest, and followed by scrub formations which are eventually substituted by subalpine meadows on the summits (Exell, 1968; Guinea, 1968; Butynski and Koster, 1989; Juste, 1992).

\section{Lowland rainforest}

This formation is found from sea level to $800 \mathrm{~m}$ elevation in Bioko (Guinea, 1951, 1968) and São Tomé (Exell, 1968) but is absent from Annobón (Jones and Tye, 1990). Characteristics are similar to the continental rainforests, in terms of its high biological diversity, elevated tree species diversity and abundance of lianas and epiphytes. Common tree species include Ceiba pentandra, Pycnanthus angolensis, Pycnanthus kombo, Erythrina senegalensis, Staudtia gabonensis, Sterculia acuminata, Clorophora excelsa as well as a variety of endemic Ficus spp. The main difference between the islands' and continental rainforest lies in the lower diversity of the islands as well as the absence of species such as okoume (Aucomaea klaineana) and creeper palms (Chevalier, 1938). On Bioko, the rainforest is distinct from the other lowland rainforest because the monsoonic climatic features of the area (Guinea, 1968).

\section{Montane forest}

Montane forest is found between $800 \mathrm{~m}$ and $1400 \mathrm{~m}$ (Guinea, 1951). A main characteristic of this vegetation type is the appearance of tree ferns (Cyathea spp.) and the increase in lichens, epiphytes, mosses and lianas on trees. The tree layer is dominated by tall stands of species such as Pycanthus microcephala, Coelocaryon preusii, Sterculia oblonga and Clorophora regia. Undergrowth is characterized by the presence of small bushes of the families Euphorbiaceae and Rubiaceae, and by the remarkable absence of Leguminosae (Exell, 1952, 1968; Figueiredo, 1994). On each island, there are numerous plant endemics within this vegetation type, e.g. the endemic pine Podocarpus mannii in São Tomé. On Príncipe, montane forest is little studied and on Annobón this formation is substituted by other more xerophytic types (Exell, 1952).

\section{Mossy forest}

From 1500 to $2500 \mathrm{~m}$ the forest changes in constituent species and facies. Rainfall is high and mist is typically common making the climate distinctly cooler. The combination of altitude and the corresponding fall in temperatures inhibits the growth of trees found at the lower altitudes. Thus, tree composition is characterized by species which are rarely or never found at lower levels such as the arborescent Araliaceae (Schleffera mannii and Schleffera hierniana) as well as Dracaena frangans, Ficus toningli and ferns (Guinea, 1951). Because of the prevailing windy conditions and high humidity trees do not grow more than $10 \mathrm{~m}$ in height (Chevalier, 1938). This vegetation is also rich in endemisms. On São Tomé mossy forest is found on Pico Calvario and Pico Grande. Strictly defined, mossy forest is not found on Príncipe but equivalent formations grow on its summits. On Annobón, vegetation similar to mossy forest appears above $500 \mathrm{~m}$ (Exell, 1952). 
Shrub formations

This type of vegetation is only found on Bioko, where it is associated with heights above $2500 \mathrm{~m}$. Here, formations are species-rich but dominated by species of temperate affinity (Hypericum lanceolatum, Agauria salicifolia and the Ericaceae Philippa manni) and extensively covered by lichens (Usnea languisima, $U$. articulata).

\section{Subalpine meadows}

Originally were found only on the summits of Pico Basile $(3011 \mathrm{~m}$ ). Grasses (Festuca scimpeana, Eragrostis mokensis) are abundant in association with lobelias (Lobelia columnaris) and orchids (e.g. Lyssochylus pourpuratus).

\section{Coastal meadows}

These savanna-type ecosystems extend along the northern part of São Tomé and Annobón as a result of rain shadows from the mountains in the south. Within this habitat, a baobab species (Adamsonia digitata) is present in São Tomé and Annobón. On São Tomé, endemisms such as a fruit bat (Tadarida tomensis) (Juste and Ibañez, 1993), the quail Coturnix delergorguei (Jones et al., 1991) and a lepidopteran Graphium leonidas are associated with the tree.

\section{Mangroves}

Small expanses of mangroves dominated by Rhizophora mangle, Laguncularia racemosa and Pandanus candelabrus are associated with the mouths of most rivers on all the Guinea islands except Annobón. Here, rivers are not wide enough to allow the development of these vegetation formations. The most important extensions are found along the mouth of the Rio Malança on São Tomé and on the Rio Tiburones on Bioko.

\section{Assessing the biological condition of the islands}

At the time of its discovery by the Portuguese in 1475, Bioko was peopled by Africans (Bubis) but the other three islands had apparently never been inhabited. Although there is still some controversy over the exact dates, São Tomé was discovered first at the end of December 1470, Annobón on New Year's Day 1471 and Príncipe on January 17. 1471 (Hodges and Newitt, 1988). Bioko was the last island to be discovered in 1475 by an expedition exploring the Cameroon coast. The island, at first called Formosa, was later named after its discoverer, Fernando Po.

The region has been affected extensively since its discovery by Europeans. In particular, major transformations have occurred after the introduction of New World crops especially sugar cane and cocoa. For example, the first settlers in São Tomé and Príncipe concentrated on extracting timber but, by 1529 , São Tomé was already the prime producer of sugar in the world. This island's strategic position, as well as that of Principe, for trade between Africa (including slaves), America and Europe promoted a considerable boom in its economy. As a direct consequence, much of the forest was cleared to accommodate expanding cultivations.

Bioko, on the other hand, was not immediately affected by European settlement as were the other islands. This was largely because the island was already inhabited by Bubis, Bantu stock people who probably settled on the island about 1000 years before 
its discovery by Europeans. Bubis are essentially sedentary farmers (Colell et al., 1994) who probably had little impact on the surrounding vegetation. However, much of the changes to the vegetation on Bioko, as indeed on the other islands, occurred following the introduction first of coffee and later cocoa in the middle of the 18th century. This immediately led to the replacement of the lowland rainforest by plantations up to $800 \mathrm{~m}$ in Bioko, where up to 91325 ha $(45.3 \%$ of the island) was planted with cocoa by the end of the 19th century. At present, excepting the forests along the south, there are only small forest patches (around 5870 ha according to Juste, 1992), along the SE part of the island. On São Tomé and Príncipe this type of forest was eliminated before those on Bioko in order to plant sugar cane. Now there are only small fragments left around the Xufexufe and Quija rivers, and along the slopes of the Io Grande (Peet and Atkinson, 1994) on São Tomé and even smaller patches on the Ribeira Porco and Ribiera São Tomé rivers on the south of Principe.

Montane forest, in contrast to lowland forest, has been less affected due to its higher elevation and rather more inhospitable climate. It is still well conserved on Bioko occupying a total of 55750 ha (Juste, 1992). On São Tomé, this vegetation type has been much more influenced by the spread of plantations especially around areas such as $\mathrm{S}$. Nicolau, Zampalma and Lagoa Amelia. Similar to montane forest, mossy forest has also suffered less, given the lack of human impact at these elevations. Other more localized vegetation types, such as mangroves, have been little affected on all of the islands, but species found in this habitat in Bioko, the Nile monitor (Varanus niloticus), the dwarf crocodile (Osteolemus teraspis) and other crocodilians (Crocodylus spp.), may have become extinct due to overexploitation (Castroviejo, 1993).

There is some doubt that savanna areas on the Guinea islands are natural formations (Amadon, 1953) because of the fact that they have been profoundly transformed by man (and possibly even enlarged) through burning and agricultural practices. This is certainly the case on São Tomé and on Annobón, these habitats have been further affected by cutting of the grass known as 'jambabu' (Heteropogon contortus) used for thatching. In general, habitats on Annobón have been proportionally much more altcred than those on the other islands because of its small size. Agriculture has taken over much of the land, in some cases even including steep slopes where traditional cropland are separated by natural forest corridors.

\section{Constraints on the conservation and sustainable use of natural resources in the Gulf of Guinea}

Equatorial Guinea exemplifies how external economic forces can control internal markets and ultimately arrest development in poor countries with fragile economies. The ensuing disruptions of commercial networks and price structures in the country (UNDP, 1991) has meant that the country can have little control over export commodities which are mainly natural products and are the main income sources. Thus, the recent devaluation of the Cefa Franc (CFA) [the currency within the Central African Bank's (UDEAC) control, to which Equatorial Guinea belongs] depressed export prices of timber, cocoa, fish and crude oil and has led to a compensatory increase in their extraction. In contrast, because São Tomé and Príncipe are not part of the UDEAC and involved in its own economic restructuring, with emphasis on privatization and a market economy away from the existing state-control, they are less affected by external 
economic vicissitudes of the region. Despite this, the export of cocoa is still the main source of income for the country.

\section{Agriculture}

Productivity of all agricultural sectors declined considerably after independence but cash crops were particularly affected. Cocoa, the most important, was extensively cultivated by Europeans in the main islands before independence. In Bioko, the expulsion or departure, of plantation owners and technicians in 1969 as well as the subsequent political upheavals, made production fall from around $38000 \mathrm{t}$ in 1966-1967 to less than $6000 \mathrm{t}$ by 1979-1980. Since 1980, there has been some slow recovery $(7500 t$ in 1990) with cocoa still providing more than one-third of total exports by value. In São Tomé and Príncipe, cocoa overtook coffee production early on as the main export crop, increased between 1881 and 1889 but dropped dramatically after 1925 because of fall in world prices, pest spread and natural loss of land fertility. Maximum production in 1925 reached $32643 \mathrm{t}$. In recent times, cocoa has never made up less than $66 \%$ of total exports.

In order to come out of the dependency on monocultures there is no doubt that diversification of export commodity products is crucial. Both in terms of land cultivated as well as in terms of the current socioeconomic dependency of the population, cocoa is a most important crop. Therefore it is ever more pressing to find crops to substitute it given the linkage with the country's future economy. However, any new produce must have the potential of being grown sustainably, and more importantly, must not require any additional infrastructure (i.e. be able to use the existing road networks, installations and irrigation systems). Development of new crops would have to face traditional inertia, as well as the lack of proper commercial networks in order to make the new products competitive.

\section{Iivestock}

Prior to independence, Bioko was self-sufficient in beef and dairy products but livestock raising disappeared from the country during the 1970s. The absence of properly structured meat production activities on the island has rapidly forced the population to turn much more to bushmeat as a source of protein. This is having dire consequences on prey populations of primates, duikers (Juste et al., in press; Fa $e t$ al., in press) and sea turtles (Castroviejo et al., 1994). Yet, in spite of the increase in market hunting, the protein content in the national diet is still very low.

\section{Fisheries}

Despite the significant extent of exclusive maritime zones (Equatorial Guinea has $300000 \mathrm{~km}^{2}$ of fishing grounds) found around the Guinea Islands, fishing is not an important activity. The fishing industry is little developed and despite efforts made by the European Union to finance research and training schemes to improve indigenous fishing operations in Bioko, São Tomé and Príncipe (Worms, in preperation), most fishing is carried out by fleets from other nations under agreements with the local governments.

\section{Forestry}

Timber operations in the Guinea islands can have important deleterious consequences for the preservation of biodiversity. At present, forestry activities are restricted to sec- 
ondary forest in old cocoa plantations but these are not well organized and are extremely disruptive (Juste, 1992). On São Tomé and Príncipe, actual wood consumption (including firewood) is around $170000 \mathrm{~m}^{2}$ (Interforest-AB, 1990). On Bioko, timber use is probably significantly higher than this, although exact figures are not available. Given that demand is likely to increase as the population increases, a strong forest management policy is needed to organize and alleviate the pressures on the Guinea islands' forests.

\section{Institutions}

Environmental initiatives in the Guinea islands are less than a decade old, and thus the governments' involvement in these activities are still maturing. Despite the fact that both governments have created national bodies to oversee environmental matters (the Comité Nacional de Proteccion del Medio Ambiente in Equatorial Guinea and the Comissao Nacional do Ambiente), these have been fraught with operational problems in carrying out their briefs. The major problem is the interministerial nature of these committees, the lack of trained personnel and resources to take action.

\section{Legislation}

New, extensive laws concerning the environment were passed in 1988. In Equatorial Guinea the decree (Ley 8/1988) regulates the use of wildlife, protected areas and hunting whilst the decree (Ley 3/1991) introduces a new legal framework for sustainable timber extraction. Both decrees are significant milestones in the organization of natural resource management and environmental protection in the country. However, there is a need for both decrees to be more interrelated and more significantly enforced. On São Tomé and Príncipe, discussions are now under way to introduce the 'Ley Quadro sobre a Politica Nacional do Ambiente' (September, 1993). As in Bioko, the value of these laws can only be seen on implementation. Neither countries have legislation that deals with water quality, housing and urbanization or land tenure.

\section{Conservation, education and community participation}

No environmental education exists at present or contemplated in the near future. Because of the current lack of resources within the educational system of the two countries, any development of conservation education programmes is limited. Especially grave is the loss of traditional knowledge of the use of resources, replaced by other values concomitant with rapid development. Non-governmental organizations have an important role to play in promoting the perpetuation of these skills and in the creation of general awareness of the environment by the local people.

\section{Recommendations for the conservation of biodiversity in the Gulf of Guinea islands}

The following recommendations arose from the Jersey workshop.

\section{Legislation and control of impact}

(i) Implement and enforce the environmental legal system.

(ii) Establish Ministries of Environmental Protection within Equatorial Guinea and São Tomé and Príncipe that will reinforce and develop an institutional framework for environmental conservation in both countries. This institution should be independent but with linkages with other ministries within the countries. 
(iii) Recent actions initiated by the Governments of Equatorial Guinea and São Tomé and Príncipe to restrict logging concessions and control wood extraction for domestic use should be continued.

(iv) Regulate and reduce pollutants, particularly those from oil, gas, pesticides and fungicides.

(v) Request environmental impact assessments for potentially damaging industries and development projects. Provisions should be made within the existing legal system. Foreign industries should follow the environmental laws of their home countries and to undertake environmental restoration when necessary.

(vi) Establish environmentally sound land-use practices and crop production schemes.

(vii) Implement the national guidelines resulting from the United Nations Environmental Action Plans or Strategies for each country.

(viii) The system of stumpage fees and other taxes regarding the exploitation of renewable natural resources should be reviewed in order to define optimal levels that would reflect the real economic value of these resources.

\section{Protected areas}

(ix) Secure the protection of representative samples of terrestrial ecosystems by developing the already decreed protected zones in all four islands: Bioko (Pico Basilé and Southern Highlands); São Tomé (Zona Ecologica); Príncipe (Zona Ecologica); Annobón Island.

(x) Investigate the feasibility of establishing all Gulf of Guinea islands as MAB Biosphere Reserves.

(xi) Identify other specific areas for biodiversity conservation on all four islands namely:

Areas for the protection of freshwater organisms (some of high endemicity) and of importance for life-support systems.

Coral reef regions of recognized world importance surrounding all islands.

\section{Species protection}

(xii) Regulate the harvesting of all species.

(xiii) Identify ways of enforcing sustainable use of animal species in particular primates, marine turtles, and marine fish.

(xiv) Develop and enforce a regional co-operation framework for the protection of migratory species or marine organisms that use territorial waters around all islands.

(xv) Identify priority species for conservation and set up surveys in order to assess their status and requirements.

\section{Education and research programmes}

(xvi) Initiate individual island conservation education programmes.

(xvii) Establish a research and environmental education centre on each island.

(xviii) Provide support and training for environmental protection.

(xix) Increase studies on biodiversity, applied ecology and socioeconomic issues. Develop monitoring programmes.

(xx) Environmental education of the general public could also include increasing awareness of locally endangered species. 
Socioeconomic development

(xxi) Study the possible introduction of an environmental tax on all exploitation of natural resources including tourism, for the use in their long term conservation.

(xxii) Develop projects for sustainable use of natural resources and improve conditions for people living around protected areas.

(xxiii) Control the impact of, and plan, tourism in line with environmental protection. Small scale eco-tourism, in which local people are involved, should be promoted by the governments.

(xxiv) The possibility of creating an environmental conservation fund for the Gulf of Guinea islands should be considered.

\section{Implementation}

During the Jersey workshop it was decided that members listed below would form a Steering Committee (The Gulf of Guinea Conservation Group) to develop and cost proposals contained in the Action Statement. This Group would seek ways of implementing the proposed steps, by working closely with international organizations and continuing liaising with the Governments of Equatorial Guinea and of São Tomé and Príncipe. An immediate objective of the Group is to convene a second meeting in the region that would bring together politicians (who have been continually informed of the efforts made) from the two countries, as well as scientists and development organizations, to discuss the practicalities of launching a joint strategy in the near future.

\section{Participants}

Mr Philip Atkinson, School of Biological Sciences, University of East Anglia, Norwich, UK. Dr Thomas Butynski, Zoo Atlanta Africa Program, Nairobi, Kenya. Mr Ramon Castelo, Asociacion Amigos de Doñana, Sevilla, Spain. Dr Javier Castroviejo, Estacion Biologica de Doñana, Sevilla, Spain. Dr Montserrat Colell, Departament de Psiquiatria e Psicobiologica Clinica, Universitat de Barcelona, Spain. Mr John Dutton, School of Biological Sciences, University of East Anglia, Norwich, UK. Mr Nicolas Egli, Conseiller a la Direction General de l'Environnement, B.P. 14536, Brazzavile, Republic of Congo. Dr John E. Fa, Jersey Wildlife Preservation Trust, Jersey, Channel Islands. Ms Estrela Figueiredo, Department of Botany, School of Plant Sciences, University of Reading, Reading, UK. Mr Angus Gascoigne, São Tomé, D.R. of São Tomé and Príncipe. Dr Carlos Ibañez, Estacion Biologica de Doñana, Sevilla, Spain. Dr Peter Jones, ICAPB (Zoology Building), University of Edinburgh, Edinburgh, UK. Dr Javier Juste, Estacion Biologica de Doñana, Sevilla, Spain. Dr Stanley Koster, Zoo Atlanta Africa Program, Nairobi, Kenya. Dr Carmen Maté, Departament de Psiquiatria e Psicobiologica Clinica, Universitat de Barcelona, Spain. Mr Nicholas Peet, School of Biological Sciences, University of East Anglia, Norwich, UK. Mr Jaime Perez del Val, Associacion Amigos de Doñana, Sevilla, Spain. Dr C. Dietrich Schaaf, Zoo Atlanta, Atlanta, USA. Ms Vanessa Sequeira, Royal Kew Gardens, Richmond, UK. 


\section{References}

Amadon, D. (1953) Avian systematics and evolution in the Gulf of Guinea. The J.G. Correia Collection. Bull. Amer. Mus. Nat. Hist. 100, 393-451.

Bibby, C.J., Collar, N.J., Crosby, M.J., Heath, M.F., Imboden, C., Johnson, T.H., Long, A.J., Stattersfield, A.J. and Thirgood, S.J. (1992) Putting diversity on the map: priority areas for global conservation. Cambridge: International Council for Bird Preservation.

Butynski, T. and Koster, S.H. (1989) The Status and Conservation of Forests and Primates on Bioco island (Fernando Poo). Equatorial Guinea. WWF Unpubl. Report, 64 pp.

Castelo, R. (1994) Biogeographical considerations of fish diversity in Bioko. Biodiv. Conser. 3 (9). $808-827$.

Castroviejo, J. (1993) Estudio sobre la zonificatión y uso múltiple de las áreas protegidas de Bioco. Unpubl. Report Forindeco, 85 pp

Castroviejo, J., Juste, J., Perez del Val, J., Castelo, R. and Gil, R. (1994) Diversity and status of sea turtle species in the Gulf of Guinea islands. Biodiver. Conserv. 3 (9), 828-836.

Capuz, R. 91961) Guía Meteorológica de las provincias de Guinea. I.E.A. (CSIC), Madrid, IEA (CSIC).

Chevalier, A. (1938) La végétation de l'île de San-Thomé. Bol. Soc. Broteriana 13, 101-16.

Colell, M., Maté, C. and Fa, J.E. (1994) Hunting among Moka Bubis in Bioko: dynamics of faunal exploitation at the village level, Biodiv. Conser. 3 (9), 939-950.

Dos Santos, P., J. (1943) Subsidios geologicos e petrográficos para o conhocemento da ilha de São Tomé. Pôrto: Moderna, Lda.

Eisentraut, M. (1963) Die Wirbeltiere des Kamerungebirges. Hamburg \& Berlin: Paul Parey.

Exell, A.W. (1944) Catalogue of the vascular plants of $S$. Tomé (with Principe and Annobón). London: British Museum (Natural History).

Exell, A.W. (1952) The vegetation of the islands of the Gulf of Guinea. Leujuinia 16, 57-66.

Exell, A.W. (1968) Príncipe, São Tomé and Annobón. In Conservation of Vegetation in Africa South of the Sahara. (I. Hedberg and O. Hedberg, eds.) Acta Phytogeographica Suecica 54. $132-6$

Exell, A.W. (1973) Angiosperms of the Islands of the Gulf of Guinea (Fernando Po, Príncipe, São Tomé and Annobón). Bull. Brit. Mus. (Nat. Hist.) Botany 48, 325-411.

Fa, J.E., Juste, B., J. Pérez del Val, J. and Castroviejo, J. Impact of Market Hunting on Mammal species in Equatorial Guinea. Conservation Biology in press.

Fahr, J. (1993) Ein Beitrag zur Biologie der Amphibien der Insel São Tomé (Golf von Guinea). Faunis. Abhandlungen 19, 75-84.

Figuerido, E. (1994) Diversity and endemism of angiosperms in the Gulf of Guinea islands. Biodiv. Conser. 3 (9), 785-793.

Fuster, J.M. (1950) Las rocas ultrabásicas de Annobón y su relación con los magmas basálticos de otras islas del Golfo de Guinea. Madrid: Arch. I.E.A. (CSIC).

Fuster, J.M. (1954) Estudio Petrogenético de los volcanes del Golfo de Guinea. Madrid: I.E.A. (CSIC).

Gascoigne, A. (1994) The biogeography of land snails in the islands of the Gulf of Guinea. Biodiversity and Conservation in the Gulf of Guinea Islands. Biodiver. Conserv. 3 (9), 794-807.

Guinea, E. (1951) Esquema de la Vegetación de Fernando Poo. Confer. Inter. Afric. Occid. Circular: 41-5.

Guinea, E. (1968) Fernando Po. In Conservation of Vegetation in Africa South of the Sahara. (1. Hedberg and O. Hedberg, eds) Acta Phytogeog. Suecica 54, 130-2.

Hodges, T. \& Newitt, M. (1988) São Tomé and Príncipe. From Plantation Colony to Microstate. Boulder and London: Westview Press.

Heim de Balsac, H. and Hutterer, R. (1982). Les Soricidae (Mammiferes, Insectivores) des iles du Golfe de Guinée: faits noveaux et problemes biogeographiques. Bonn. Zool. Beitr. 33, 133-50. 
Interforest-AB (1990) RDSTP. National Forest Inventory: Study of supply and demand of primary forest products. Unpublished Report.

Jones, P.J. (1994) Biodiversity in the Gulf of Guinea: An overview. Biodiver. Conserv. 3 (9), $772-$ 784.

Jones, P.J. and Tye, A. (1980) A survey of the avifauna of São Tomé and Príncipe. ICBP study report 24. Cambridge: ICBP.

Jones, P.J., Burlison, J.P. and Tye, A. (1991) Conservação dos ecossistemas florestais na República democrática de São Tomé e Principe. Cambridge: UICN/Comissão das Comunidades Européias.

Juste, B., J. (1992) Zonificación ecológica y evaluación del impacto ambiental de los usos actuales en la isla de Bioco. FO UTF/EQG/002/EQG. Field Doc. No.2. FAO, Unpublished Report, $75 \mathrm{pp}$.

Juste, B., J. and Ibáñez, C. (1993) A new Tadarida of the subgenus Chaerephon (Chiroptera: Molossidae) from São Tomé Island, Gulf of Guinea (West Africa). J. Mammal. 74, 901-11.

Juste, B., J. and Ibáñez, C. (1994) Bats of the Gulf of Guinea Islands: Faunal composition and origins. Biodiver. Conserv. 3 (9), 837-850.

Kingdon, J. (1990) Island Africa. London: W. Collins \& Sons.

Louzoun, G. (1985) Le Climat, pp. 33-53. Project Carte des potentiales agricoles. Unpublished report. Ministerio de Agric. y Pecuaria. RDSTP.

Peet, N. and Atkinson, P. (1994) Biodiversity and Conservation of the birds in São Tomé and Príncipe. Biodiver. Conserv. 3 (9), 851-867.

Terán, M. (1962) Sintesis geográfica de Fernando Poo. Madrid: IEA \& Inst. Juan Sebastián Elcano (CSIC).

UNDP (1991) Guinea Ecuatorial: Evolución Económica reciente y fundamentos para una estrategia alternativa de desarrollo. P. Larrainz. Unpublished Report.

Viejo, J.L. (1990) Consideraciones biogeográficas sobre las mariposas de las islas del Golfo de Guinea (Lepidoptera: Papilionoidea). SHILAP Revta, Lepid. 18, 239-51.

Wauthy, B. (1983). Introduction à la climatologie du Golfe de Guinée. Océanogr. Trop. 18 (2), 103-38.

Worms, J. A preliminary annotated list of Commercial fish of São Tomé Island, Gulf of Guinea, West Africa. 8 pp. In press. 